\title{
INFLUENCE OF THE BALL MILLING PROCESS AND AIR SINTERING CONDITIONS ON THE SYNTHESIS OF $\mathrm{La}_{0.7} \mathrm{Sr}_{0.3} \mathrm{MnO}_{3}$ CERAMICS
}

\begin{abstract}
ENIKŐ BITAYa*, ANA-MARIA PILBAT ${ }^{\mathrm{b}}$, EMIL INDREA ${ }^{c}$, IRÉN KACSÓc, MÁRTON MÁTÉ ${ }^{a}$, ATTILA LEVENTE GERGELYa, ERZSÉBET VERESS ${ }^{{ }^{*}}$
\end{abstract}

\begin{abstract}
Conventional solid-state synthesis was used to produce mixed valence manganite $\mathrm{La}_{0.7} \mathrm{Ca}_{0.3} \mathrm{MnO}_{3}$ (LCMO) from the mechanochemically activated mixture of the corresponding metal oxides. Prepared samples were characterized by XRD and SEM measurements. The results showed that it is possible to produce single phase LCMO perovskite after at least $2 \mathrm{~h}$ of ball milling of the reaction mixture, followed by $1400^{\circ} \mathrm{C}$ sintering of the drypressed sample pellets. The prolonged milling time as well as the higher sintering temperature leads to further stabilization of crystal structure.
\end{abstract}

Keywords: perovskite manganites, LCMO, mechanochemical synthesis, $X R D, S E M$, microstructural characterization

\section{INTRODUCTION}

Due the practical significance of their outstanding magneto-electric properties (high temperature superconductivity, huge magneto-resistance, magneto-caloric and magneto-optical effect, spin-glass state), there is an ever growing interest towards the mixed oxidic ceramic systems containing transition

\footnotetext{
a Sapientia Hungarian University of Transylvania, Faculty of Technical and Human Sciences, OP 9 CP 4, RO-540485 Targu-Mures, Romania

b Institute of Biochemistry, Biological Research Centre of the Hungarian Academy of Sciences, Temesvári krt. 62, H-6726 Szeged, Hungary

c National Institute for Research and Developement of Isotopic and Molecular Technologies, Donath Str. 65-103, RO-400293 Cluj, Romania

d Transylvanian Museum Society, Napoca Str. 2-4, RO-400750 Cluj, Romania

*Corresponding authors: ebitay@ms.sapientia.ro; veresserzsebet@gmail.com
} 
metals and/or REE (perovskites, spinels, pyrochlores) [1]. The peculiar properties of these materials result from local micro-structural electric and magnetic phase transitions. The colossal magnetic resistant (CMR) behavior of perovskites, e.g., can be associated to the paramagnetic-ferromagnetic phase transition taking place when the temperature decreases below a critical value (the Curie point, $T_{C}$ ) [2].

Nowadays, study is mainly focused on CMR manganite perovskites of the general formula $A_{1-x} A_{x}^{\prime} M_{n n} O_{3}\left(A-M^{3+}\right.$, e.g. La and $A^{\prime}=M^{2+}$, e.g. $\mathrm{Ca}$, $\mathrm{Sr}, \mathrm{Ba})$, where $\mathrm{La}_{1-x} \mathrm{~A}_{x}^{\prime} \mathrm{MnO}_{3}(0<x<1)$ mixed manganites (parent compound: $\mathrm{LaMnO}_{3}$ ) are the representative ("prototype") CMR ceramic family. Replacement of La with divalent cations oxidizes $\mathrm{Mn}^{3+}$ to $\mathrm{Mn}^{4+}$, introduces holes in the $\mathrm{Mn}$ $3 \mathrm{~d}$ band and induces the metallic and/or ferromagnetic behavior ("oxidative nonstoichiometry"). Considering the ease of the oxidation process $\mathrm{Mn}^{3+} \rightarrow$ $\mathrm{Mn}^{4+}+1 \mathrm{e}^{-}$, such a defective material is formed also by annealing $\mathrm{LaMnO}_{3}$ in air or $\mathrm{O}_{2}$ atmosphere. As insertion of excess oxygen is not possible in the perovskite structure, the global composition resulted due to the non-stoichiometric incorporation, via cation vacancies, will be $\mathrm{LaMnO}_{3+\delta}$ [2]. In fact, the mixed manganites' general but correct crystallographic formula is $\mathrm{La}_{1-x} \mathrm{Mn}_{1-x} \mathrm{O}_{3}, x=$ $\delta /(3+\delta)$.

The presence of mixed $\mathrm{Mn}^{3+}-\mathrm{Mn}^{4+}$ valences gives rise to a doubleexchange mechanism which, together with the charge ordering and the strong electron-phonon coupling (of a type of dynamic extended system version of the Jahn-Teller effect), are at the origins of: the sharp increasing of the electrical conductivity, the ferromagnetic-like behavior with reentrant spin-glass character, the large magnetoresistance, as well as the unusual magneto-caloric and magneto-elastic effects observed near the phase transition temperature. Divalent cation substitution for $\mathrm{La}$ is particularly effective in the doping range of $x \approx 0.2-0.4$ (20-40\% holes/Mn ion), with the phase transition temperature exceeding room temperature in some cases (in the $\mathrm{La}_{1-x} \mathrm{Ca}_{x} \mathrm{MnO}_{3}$ system $\mathrm{T}_{\mathrm{C}}$ varies between 182 and $278 \mathrm{~K}$ ) [3].

The special phase transition related magneto-electric properties of the manganites can be controlled through their synthesis method (and conditions), chemical composition, temperature, pressure, external magnetic field strength, hence offering them a great variety of applications.

This paper presents a preliminary XRD and SEM study of $\mathrm{La}_{0.7} \mathrm{Ca}_{0.3} \mathrm{MnO}_{3+\delta}$ samples, prepared by the standard ceramic technology, with the aim of establishing the influence of the mechanical activation (the ball milling time) and the firing conditions (time and temperature) on the phase composition and the microstructural characteristics of the obtained ceramic material. 
INFLUENCE OF THE BALL MILLING PROCESS AND AIR SINTERING CONDITIONS ON THE SYNTHESIS OF $\mathrm{La}_{0.7} \mathrm{Sr}_{0.3} \mathrm{MnO}_{3}$ CERAMICS

\section{RESULTS AND DISCUSSION}

\section{$\mathrm{La}_{0.7} \mathrm{Ca}_{0.3} \mathrm{MnO}_{3+\delta}$ synthesis and characterization}

Mixed-valence manganites destined for practical applications are prepared most frequently as thin films (mostly by sol-gel dip coating, spray pyrolysis or electrochemical deposition; sputtering, PLD from ceramic targets, MOCVD or MBE) and nanoparticles (by sol-gel route, combustion - autocombustion, precipitation from aqueous or non-aqueous solution, from reversal microemulsions). Single crystals, obtained usually by the flux melt technique, floating zone melting, hydrothermal synthesis, sol-gel method, etc. are used generally for research purposes [1, 4].

Bulk polycrystalline ceramics are most easily prepared by the standard ceramic method: repeated grinding, compaction and firing of the stoichiometric mixture of the oxide components, until a single-phase material is achieved. To obtain $\mathrm{La}_{1}{ }_{x} \mathrm{Ca}_{x} \mathrm{MnO}_{3}$, a mixture of $\mathrm{La}_{2} \mathrm{O}_{3}, \mathrm{CaO}$ and $\mathrm{MnO}_{2}$ has to be grinded together, pelleted and fired in air for several hours. The process has to be repeated as many times as necessary, until the uniform single phase material is obtained. Since the method depends on the solid-state interdiffusion between the oxides, a finely powdered, well-compacted starting mixture has to be used. A variant of the method uses previously dried precursors (typically carbonates or oxalates) which decompose into highly reactive, ultrafine-grained oxides during a preliminary calcination. The starting oxide mixture can be obtained also in form of a precursor gel by wet chemical methods (co-precipitation), or from a citrate gel, by dissolving $\mathrm{La}_{2} \mathrm{O}_{3}, \mathrm{CaCO}_{3}$ and $\mathrm{MnCO}_{3}$ in $\mathrm{HNO}_{3}$, then adding citric acid and ethylene glycol [4].

The present study investigates the ball milling time and firing conditions influence on reaction completion for the standard solid state synthesis of polycrystalline $\mathrm{La}_{0.7} \mathrm{Ca}_{0.3} \mathrm{MnO}_{3+\delta}$ ceramics (LCMO).

For this purpose, four series of LCMO ceramics were prepared starting from the stoichiometric mixture of high purity of dried $\mathrm{La}_{2} \mathrm{O}_{3}, \mathrm{MnO}_{2}$ and $\mathrm{CaCO}_{3}$ (Table 1). Starting mixtures of identical composition were homogenized, pulverized and mechanically activated by 1,2 and 3 hours of ball milling, then pelletized, and fired during $2 \mathrm{~h}$ at $1200^{\circ} \mathrm{C}$ (samples 12.1, 12.2 and 12.3 ); $2 \mathrm{~h}$ at $1200^{\circ} \mathrm{C}$ then $2 \mathrm{~h}$ at $1300^{\circ} \mathrm{C}$ (samples $13.1,13.2$ and 13.3); and $2 \mathrm{~h}$ at $1200^{\circ} \mathrm{C}, 2 \mathrm{~h}$ at $1300^{\circ} \mathrm{C}$, then $2 \mathrm{~h}$ at $1400^{\circ} \mathrm{C}$ (samples 14.1 , 14.2, 14.3, and respectively 14.1.L, 14.2.L, 14.3.L). In the end, excepting samples 14.1.L, 14.2.L and 14.3.L which were left in the oven to self-cool up to room temperature, all others were rapidly cooled by quenching. 
ENIKŐ BITAY, ANA-MARIA PILBAT, EMIL INDREA, IRÉN KACSÓ, MÁRTON MÁTÉ,

ATTILA LEVENTE GERGELY, ERZSÉBET VERESS

Table 1. The list of prepared LCMO ceramics

\begin{tabular}{|c|c|c|c|c|c|}
\hline & \multirow{4}{*}{$\begin{array}{c}\text { Sample } \\
\text { coding }\end{array}$} & $\begin{array}{c}\text { Milling } \\
\text { time }\end{array}$ & \multicolumn{5}{|c|}{$\begin{array}{c}\text { Firing time } \\
\text { (h) }\end{array}$} \\
\cline { 3 - 6 } & $\mathbf{1 2 0 0 ^ { \circ } \mathrm { C }}$ & $\mathbf{1 3 0 0}^{\circ} \mathrm{C}$ & $\mathbf{1 4 0 0}^{\circ} \mathrm{C}$ & $\mathbf{1 4 0 0}^{\circ} \mathbf{C}$ \\
\hline 12.1 & 1 & 2 & & & \\
\hline 12.2 & 2 & 2 & & & \\
\hline 12.3 & 3 & 2 & & & \\
\hline 13.1 & 1 & 2 & 2 & & \\
\hline 13.2 & 2 & 2 & 2 & & \\
\hline 13.3 & 3 & 2 & 2 & & \\
\hline 14.1 & 1 & 2 & 2 & 2 & \\
\hline 14.2 & 2 & 2 & 2 & 2 & \\
\hline 14.3 & 3 & 2 & 2 & 2 & \\
\hline $14.1 . L^{*}$ & 1 & 2 & 2 & & 2 \\
\hline $14.2 . L^{*}$ & 2 & 2 & 2 & & 2 \\
\hline $14.3 . L^{*}$ & 3 & 2 & 2 & & 2 \\
\hline
\end{tabular}

*self-cooled

The LCMO phase formation for syntheses carried out according to the conditions presented in Table 1 was determined by XRD analysis. Phase purity of the ceramic samples (regarded as reaction efficiency) was estimated on the basis of the recorded diffractograms. The one corresponding to the 14.3.L sample is presented in Figure 1.

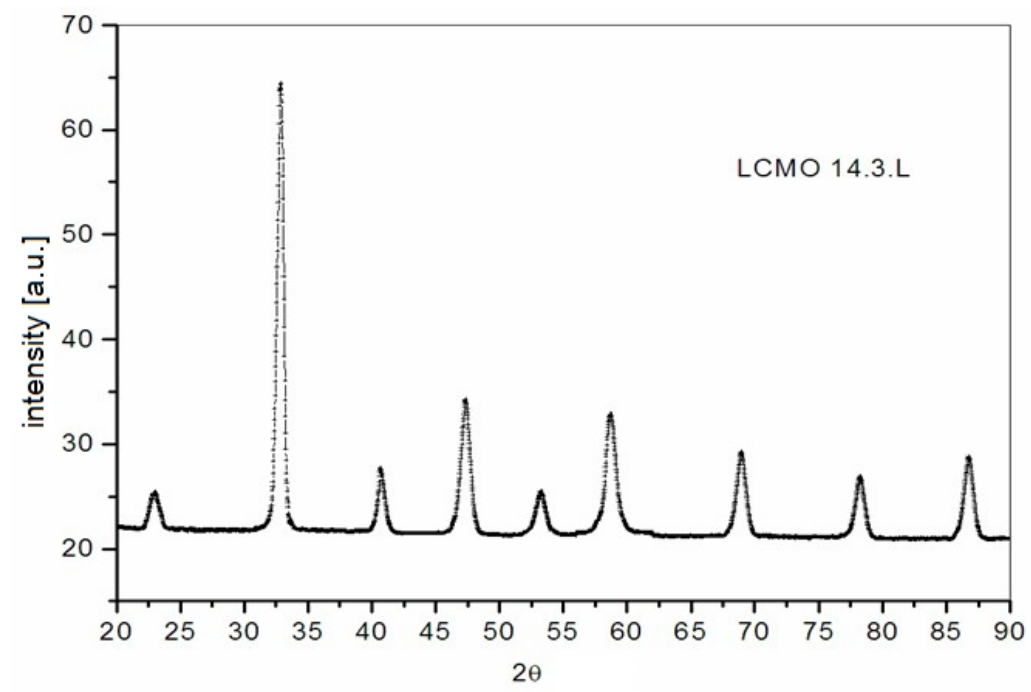

Figure 1. Experimental X-ray pattern of LCMO sample 14.3.L. 
The microstructural data (lattice constants, unit cell volumes, density) were calculated by assuming an orthorombic crystal structure (space group Pnma, RGNR 62); Rietveld analysis was performed by using the PowderCell 2.4 program and the data set presented in Table 2 [5-8].

Table 2. Data set used for the Rietveld refinement* (reference unit cell constants of LCMO and the atomic positions)

$\begin{array}{lcccccc}\text { CELL } & 5.4650 & 7.7231 & 5.4798 & 90.000 & 90.000 & 90.000 \\ \text { La } & 57 & 1.0000 & 0.2500 & 1.0000 & 0.7000 & (4 c) \\ \text { Ca } & 20 & 1.0000 & 0.2500 & 1.0000 & 0.3000 & (4 c) \\ \text { Mn } & 25 & 0.0000 & 0.0000 & 0.5000 & & (4 b) \\ \text { O1 } & 8 & 0.5000 & 0.2500 & 1.0000 & & (4 c) \\ \text { O2 } & 8 & 0.7524 & 0.0000 & 0.3000 & & (8 d)\end{array}$

( ${ }^{*}$ orthorombic system, RGNR 62 Pnma).

XRD patterns recorded for the ceramic samples did in neither case reveal impurity phases. Thus, it may be concluded that the synthesis was fairly completed even for the mildest employed reaction conditions (2 hours of firing at $1200^{\circ} \mathrm{C}$ after only 1 hour of milling). However, it must be taken into account that XRD evidences only mineral phases over $2-3 \mathrm{wt} \%$.

In order to compute the microstructural parameters, experimental XRD data were considered only in the $2 \theta$ intervals 28 to 35 and 55 to 62 , respectively, in the domain of most intensive peaks (Table 3 ). Possible changes of the lattice parameters were also taken into account.

Table 3. Parameters of the main XRD peaks for sample 14.3.L.

\begin{tabular}{rrrrrrrrr}
$\mathrm{H}$ & $\mathrm{K}$ & $\mathrm{L}$ & $2 \theta\left[{ }^{\circ}\right]$ & $\mathrm{d}[\AA \AA \AA$ & \multicolumn{1}{c}{$\mathrm{I}_{\mathrm{abs}}$} & $\mathrm{F}(\mathrm{hkl}) \mid$ & $\mathrm{Mu}$ & $\mathrm{FWHM}$ \\
\hline 0 & 0 & 2 & 32.657 & 2.73990 & 264.51 & 211.37 & 2 & 0.2236 \\
1 & 2 & 1 & 32.737 & 2.73336 & 967.48 & 202.42 & 8 & 0.2236 \\
2 & 0 & 0 & 32.748 & 2.73250 & 241.26 & 202.21 & 2 & 0.2236 \\
2 & 1 & 0 & 34.798 & 2.57602 & 0.00 & 0.00 & 4 & 0.2236 \\
1 & 2 & 3 & 58.332 & 1.58062 & 309.87 & 166.28 & 8 & 0.2236 \\
0 & 4 & 2 & 58.427 & 1.57827 & 166.31 & 172.46 & 4 & 0.2236 \\
3 & 2 & 1 & 58.447 & 1.57777 & 308.34 & 166.09 & 8 & 0.2236 \\
2 & 4 & 0 & 58.485 & 1.57685 & 154.78 & 166.49 & 4 & 0.2236 \\
2 & 3 & 2 & 59.741 & 1.54667 & 0.00 & 0.00 & 8 & 0.2236 \\
2 & 0 & 3 & 60.963 & 1.51856 & 0.00 & 0.53 & 4 & 0.2236 \\
3 & 0 & 2 & 61.033 & 1.51698 & 1.61 & 17.47 & 4 & 0.2236 \\
1 & 4 & 2 & 61.063 & 1.51630 & 3.22 & 17.48 & 8 & 0.2236 \\
2 & 4 & 1 & 61.105 & 1.51536 & 0.01 & 0.85 & 8 & 0.2236
\end{tabular}


Microstructural parameters calculated for the samples 14.3 and 14.3.L are presented in Table 4. Agreement among the unit cell edge values was obtained, and the reference values confirm the orthorombic lattice structure.

Table 4. Microstructural parameters of samples 14.3 and 14.3.L.

\begin{tabular}{|c|c|c|c|c|c|}
\hline Sample & $\begin{array}{l}\mathrm{a} \\
\hat{A}\end{array}$ & $\begin{array}{l}\mathbf{b} \\
\AA\end{array}$ & 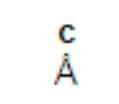 & $\underset{\AA^{3}}{V}$ & $\underset{\mathrm{g} / \mathrm{cm}^{3}}{\rho}$ \\
\hline 14.3. L & $5.46(1)$ & $5.48(1)$ & $7.72(7)$ & 231.283 & 6.032 \\
\hline 14.3. & $5.45(6)$ & $5.47(4)$ & $7.71(4)$ & 230.387 & 6.179 \\
\hline Reference value $^{*}$ & 5.4650 & 5.4798 & 7.7231 & & \\
\hline
\end{tabular}

${ }^{*}$ RGNR 62 Pnma [9]

The microstructural data of Table 4 are also in agreement with the similar values published in the literature, the differences being generally within the permitted experimental errors interval (Table 5).

Table 5. Lattice parameters of LCMO ceramics obtained by different methods

\begin{tabular}{|c|c|c|c|c|c|}
\hline Sample type & a & $\begin{array}{l}\mathbf{b} \\
\AA\end{array}$ & $\begin{array}{l}\mathbf{c} \\
\AA\end{array}$ & Observations & Ref. \\
\hline Self-combustion & 5.445 & 5.475 & 7.720 & SHS & [10] \\
\hline Sol-gel & 5.3761 & 5.3739 & 7.5715 & $\mathrm{La}_{0}{ }_{3} \mathrm{Ca}_{0}{ }_{7} \mathrm{MnO}_{3}$ & [11] \\
\hline \multirow{3}{*}{ Epitaxial thin film } & 5.433 & 5.446 & 7.842 & Carrier:: LAO & \multirow{3}{*}{ [12] } \\
\hline & 5.461 & 5.495 & 7.798 & Carrier:: $\mathrm{YAO}$ & \\
\hline & 5.488 & 5.553 & 7.690 & Carrier:: STO & \\
\hline Conventionally sintered & 5.458 & 5.458 & 15.44 & $\begin{array}{l}\text { Pseudocubic double } \\
\text { perovskite structure }\end{array}$ & [13] \\
\hline
\end{tabular}

Even if the $\mathrm{La}_{0.7} \mathrm{Ca}_{0.3} \mathrm{MnO}_{3}$ phase is present starting with ceramic samples fired at $1200^{\circ} \mathrm{C}$, the materials sintered below $1400^{\circ} \mathrm{C}$ are quite pulverulent, and the fit of the calculated diffractograms is totally satisfying for samples 14.2., 14.3. and 14.3.L only (Figure 2). In conclusion, in order to obtain a qualitatively adequate end-product, at least 2 hours milling time and at least $1400^{\circ} \mathrm{C}$ firing temperature is required. 


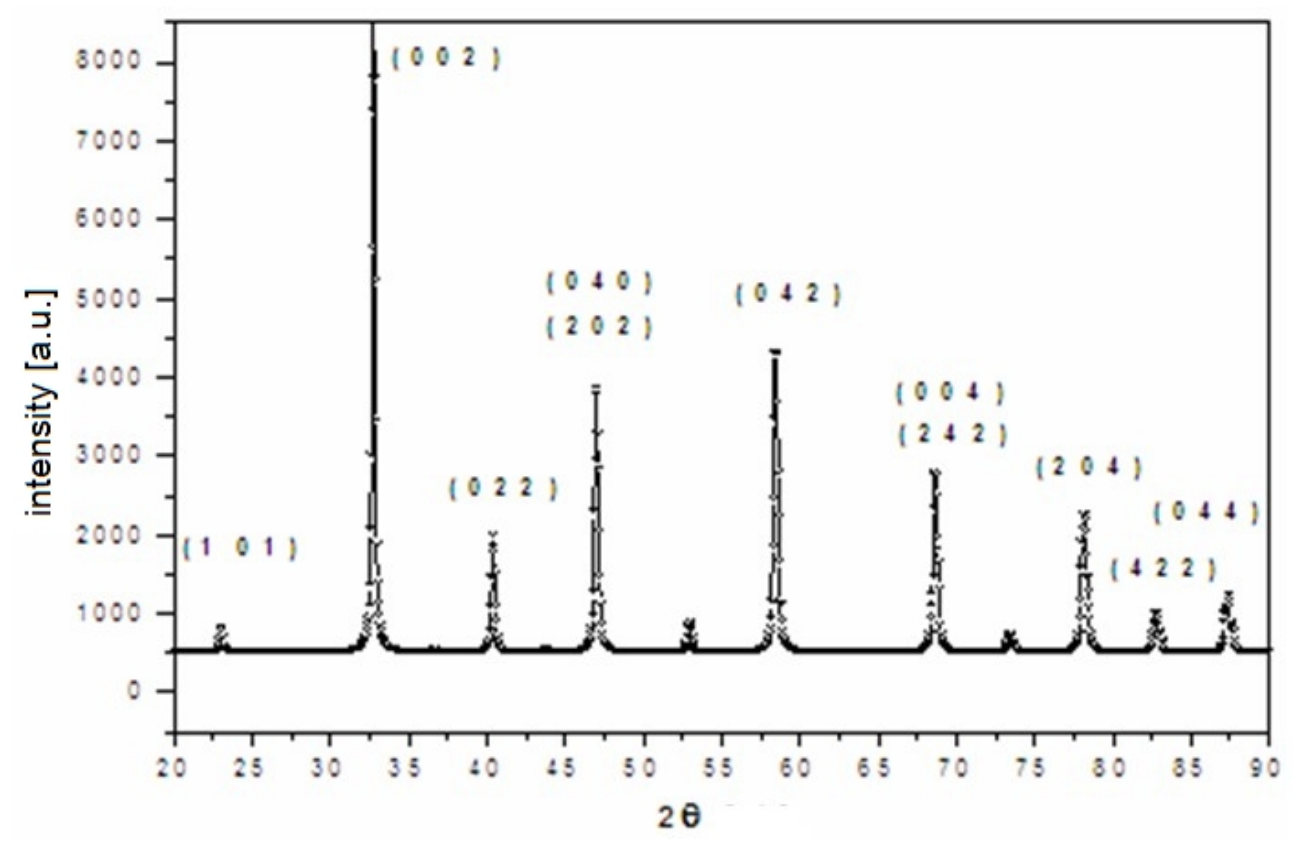

Figure 2. Calculated X-ray pattern of LCMO sample 14.3.L.

Due to their pulverulency, an adequate SEM investigation of the synthesized ceramics was possible only in case of the samples fired at $1400^{\circ} \mathrm{C}$.

As shown by the microphotos registered at $1 \mathrm{k}$ magnification, the general morphology is very similar, although the structure of the quenched samples shows a more crystalline character (Figure 3).

The differently colored, lighter and darker zones probably correspond to the differently ordered magnetic phases.

At larger (50k) magnification the microphotos evidence that whereas the structure of the quenched sample (14.2) is constituted of regular perovskite crystals, the corresponding slowly cooled 14.2.L crystalline structure is already partly melted (Figure 4). 
ENIKŐ BITAY, ANA-MARIA PILBAT, EMIL INDREA, IRÉN KACSÓ, MÁRTON MÁTÉ, ATTILA LEVENTE GERGELY, ERZSÉBET VERESS

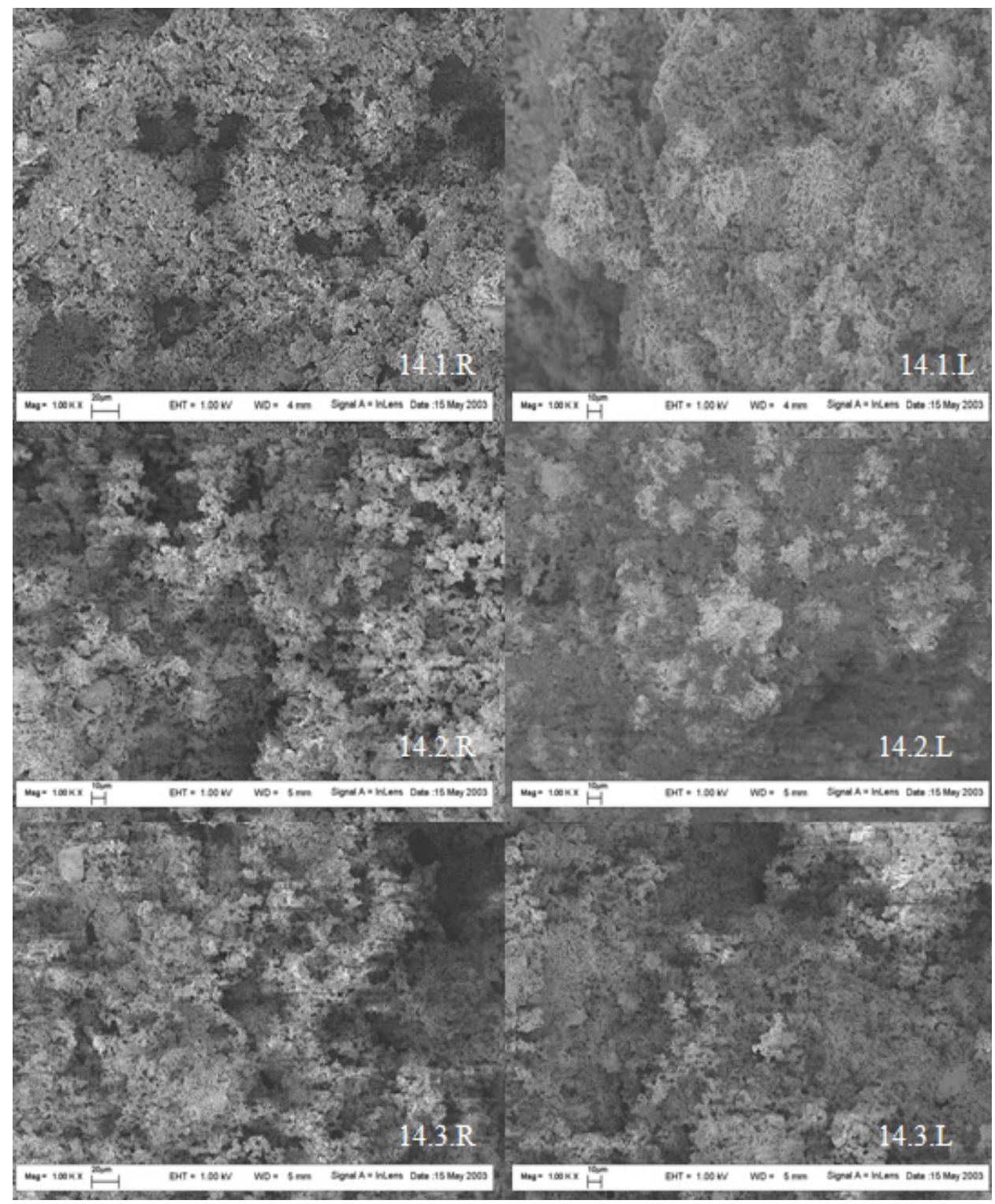

Figure 3. Milling time influence on the structure of the LCMO ceramics sintered at $1400{ }^{\circ} \mathrm{C}$ (magnification: $1 \mathrm{k}$ ). 


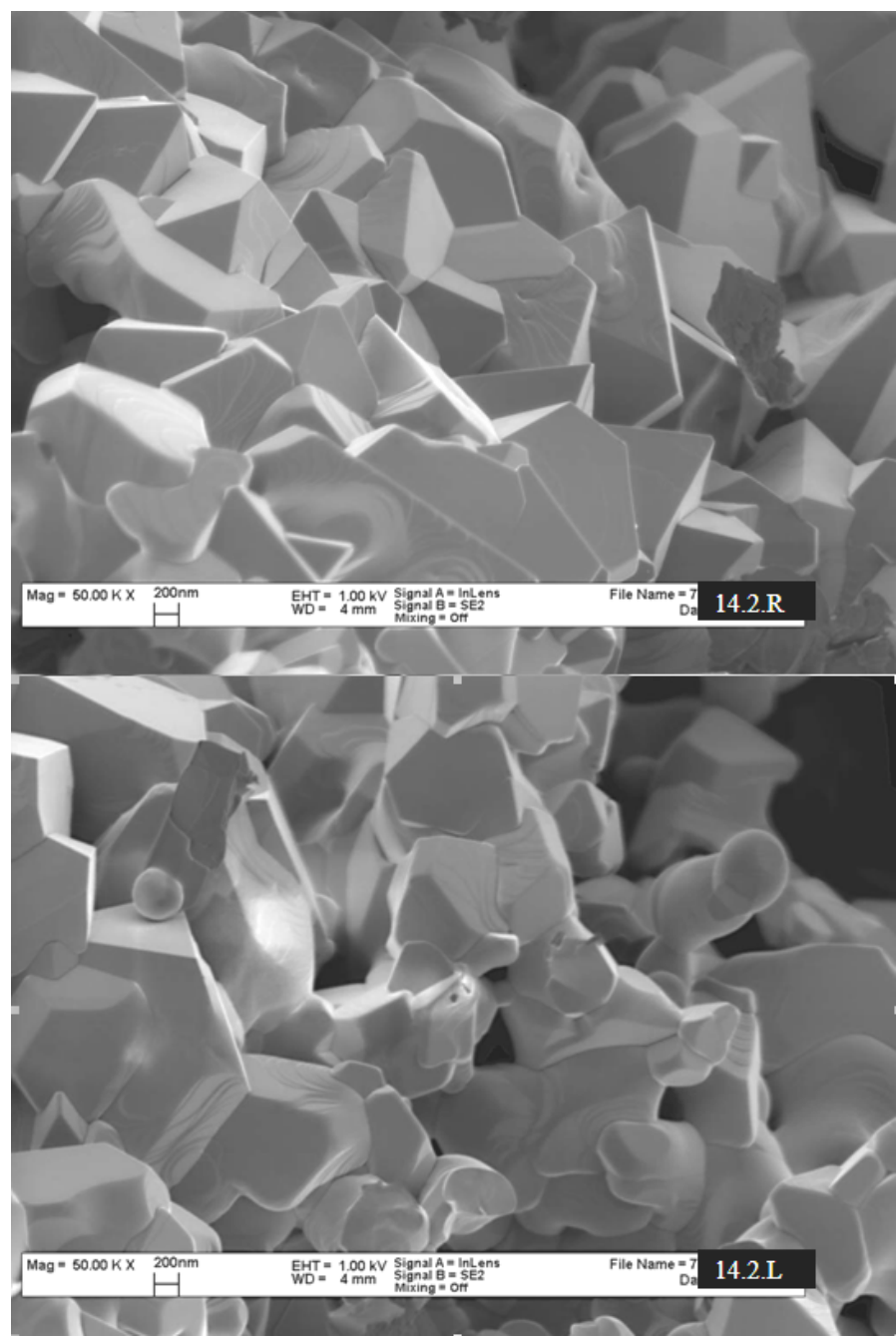

Figure 4. Perovskite crystals in the quenched (here noted as 14.2.R) and the slowly cooled (14.2.L) LCMO manganite.

\section{CONCLUSIONS}

X-ray diffractograms prove that the $\mathrm{La}_{0.7} \mathrm{Ca}_{0.3} \mathrm{MnO}_{3}$ phase is present starting with ceramic samples fired at $1200^{\circ} \mathrm{C}$. However, the materials sintered below $1400^{\circ} \mathrm{C}$ are pulverulent, and the fit of the calculated diffractograms is totally satisfying for the samples 14.2., 14.3. and 14.3.L only. A qualitatively adequate end-product necessitates at least 2 hours milling time and at least $1400^{\circ} \mathrm{C}$ firing temperature. 
ENIKŐ BITAY, ANA-MARIA PILBAT, EMIL INDREA, IRÉN KACSÓ, MÁRTON MÁTÉ, ATTILA LEVENTE GERGELY, ERZSÉBET VERESS

The calculated microstructural parameters agree well with previously published values, as well as with the generally accepted reference values, confirming together with the 50k magnification SEM images, the occurence of the orthorombic lattice structure.

\section{EXPERIMENTAL}

XRD analysis was performed using a BRUKER D8 Advance diffractometer (working parameters: $45 \mathrm{kV}, 45 \mathrm{~mA}$, Ni filtered $\mathrm{Cu} \mathrm{K}_{\alpha}$ radiation collimated with Soller slits, step-scanning mode with $\Delta 2 \theta$ of $0.01^{\circ}$ steps, spectral pure $\mathrm{Al}_{2} \mathrm{O}_{3}$ as internal standard). The sample support was uniformly coated with the finely pulverized ceramic sample (agate ball mill, mean particle diameter $<63 \mu \mathrm{m}$, PVC-based adhesive). The crystalline phase composition was determined be means of the MATCH! phase identification software and the IUCr/COD/AMCSD reference database.

SEM investigations were carried out by using a LEO 1540 XB (Gemini) microscope, on samples covered with a vacuum evaporated gold film of $\approx 10 \mathrm{~nm}$ thickness.

\section{REFERENCES}

1. J. Alonso, J.M. Barandiarán, L.F. Barquín, A. García-Arribas, Magnetic Nanoparticles, Synthesis, Properties, and Applications, In Magnetic Nanostructured Materials: From Lab to Fab, A.A., El Gendy, J.M. Barandiarán, R.L. Hadimani, Eds., Elsevier, 2018, 1-40.

2. A.P. Ramirez, Journal of Physics: Condensed Matter, 1997, 9, 8171.

3. J.A. Alonso, D. Khomskii, J.M.D. Coey, G.A. Gehring, M. Blamire, S.W. Cheong, P.C. Riedi, N.D. Mathur, D.M. Edwards, J.P. Attfield, P. Battle, Philosophical Transactions: Mathematical, Physical and Engineering Sciences, 1998, 1617.

4. J.M.D. Coey, M. Viret, S. Von Molnar, Advances in physics, 1999, 48, 167.

5. H. Rietveld, Journal of applied Crystallography, 1969, 2, 65.

6. P.R. Sagdeo, S. Anwar, N.P. Lalla, Powder diffraction, 2006, 21, 40.

7. W. Kraus, G. Nolze, PowderCell. Version 2.4. Federal Institute for Materials Research and Testing, Berlin, 1999.

8. G. Nolze, PowderCell: A mixture between crystal structure visualizer, simulation and refinement tool. In Powder Diffraction: Proceedings of the II International School on Powder Diffraction, 2002, 146.

9. T. Sudyoadsuk, R. Suryanarayanan, P. Winotai, L.E. Wenger, Journal of magnetism and magnetic materials, 2004, 278, 96.

10. A.V. Boris, N.N. Kovaleva, A.V. Bazhenov, A.V. Samoilov, N.C. Yeh, R.P. Vasquez, Journal of applied physics, 1997, 81, 5756.

11. Y.H. Li, F. Damay, L.F. Cohen, K.A. Thomas, A.K. Hossain, J.L. MacManusDriscoll, Journal of the American Ceramic Society, 2001, 84, 747.

12. G. Ceder, K. Persson, The Materials Project: A Materials Genome Approach to accelerating materials innovation, 2010, APL Materials, 2013, 1, 011002.

13. A. Gómez, E. Chavarriaga, I. Supelano, C.A. Parra, O. Morán, AIP Advances, 2018, 8, 056430. 